\title{
Effect of Plant Growth Regulators on Growth and Yield of Bottle Gourd (Lagenaria siceraria (Mol.) Standl.)
}

\author{
Komal Kumari*, Kamalkant, Randhir Kumar and Vijay Kumar Singh \\ Department of Horticulture (Vegetable \& Floriculture), Bihar Agricultural University, Sabour \\ (Bhagalpur) - 813210 , India \\ *Corresponding author
}

\section{A B S T R A C T}

Keywords

Plant Growth Regulator (PGRs), Growth trait, Distilled water, Naphthalene acetic acid and Foliage application

Article Info

Accepted:

15 June 2019

Available Online: 10 July 2019
An experiment was conducted in bottle gourd to study the effect of three plant growth regulator (PGR) viz., gibberellic acid $\left(\mathrm{GA}_{3}\right)$, Naphthalene acetic acid (NAA)and ethrel for growth trait and fruit characters of bottle gourd foliage application of Ethrel @ 200 ppm was found beneficial for number of fruits per vine, fruit yield ( $\mathrm{kg} / \mathrm{vine})$, days to $1^{\text {st }}$ harvest, whereas maximum fruit length, fruits weight and fruits girth was obtained by the application of distilled water however maximum vine length, total number of node per vine was obtained by the foliage application of $\mathrm{GA}_{3} @ 150$ ppm. Based on these observations, it could be suggested that the significant increase in growth and fruit characters would be obtained by the spraying of ethrel $200 \mathrm{ppm}$ at 2 and 4 true leaves.

\section{Introduction}

Bottle gourd (Langeraria sicenaria (monlina) standl.) is a photo-insensitive crop but sensitive to thermoperiodism. Thus, most of the existing bottle gourd varieties are season specific. It is rich in vitamin ' $\mathrm{B}$ ' and source of minerals viz., $\mathrm{P}, \mathrm{Ca}$ and $\mathrm{Fe}$. It is also important for medicinal use as ion case of headache, urines trouble and jaundice. Bottle gourd production has been increased considerably to meet the increasing internal demands as well as to open the export market abroad. The yield of cucurbit depends to a great extent on sex expression and sex ratio. Early nodes bear male flowers and higher amounts whereas hermaphrodites and pistillate flowers are found in later nodes. These results are in delaying harvesting as well as yield reduction. The problem can be defeat by exogenous application of PGRs. PGRs directly affect male and female flower ratio, fruit set, fruit drop and ultimately effects yield (Bose $e t$ al., 1999). Therefore, the use of PGRs like NAA, Ethrel and $\mathrm{GA}_{3}$ in bottle gourd may become an important tool for yield increase as well as timely harvest. Sharma et al., (1998) 
revealed that spray of NAA increased vine length, female flowers and yield in bottle gourd. Ethrel is used for more number of female flowers due to its property of better development of gynoecium, fruit ripening, stress induction, lateral cell expansion (Taiz and Zeiger, 2002). The increase in female flowers, fruit and yield in bottle gourd with application of Ethrel has been reported by Belhelkar et al., (2006). $\mathrm{GA}_{3}$ are responsible for shoot growth by enhancing cell elongation and cell division.

\section{Materials and Methods}

The field trial was conducted at vegetable section of Horticulture garden under the faculty of agriculture, Agricultural University Sabour, Bhagalpur, Bihar, India during Rabi season 2018-19 which is geographically situated between $25^{\circ} \mathrm{C}$ ' $15^{\prime} 40^{\prime}$ ' $\mathrm{N}$ latitude to $87^{\circ} 2^{\prime} 42^{\prime}$ 'Elongitude at $46 \mathrm{~m}$ above mean sea level. The climate of this place is tropical to sub-tropical with slight semi-arid nature and is characterized by very dry summer, moderate rainfall and very cold winter. During growing season, the maximum and minimum temperatures were recorded to be $33.3^{\circ} \mathrm{C}$ and $5.6^{\circ} \mathrm{C}$, respectively. Soil of the field was well drained sandy-loam in nature with rich in organic matter with good fertility status. Leveled soil surface with assured irrigation facility with expected winter and summer rain during the cropping period.

The experimental material consisted of Narendra Rashmi cultivar of bottle gourd, which is released from Main Vegetable Research Station NDAU and T Faizabad, U.P. Experiment was laid out in Randomized Block Design with three replications. Three PGRs viz., GA (gibberellic acid), Naphthalene acetic acid (NAA) and ethrel (2-chloroethyl phosphoric acid) were used for study. Seed treatment by carbendazim solution@ $0.2 \%$ for 12 hours in combination with two sprays of each PGR at 2 and 4 true leaf stages with the Altogether 10 treatment combination was made for the field trial. Plant geometry of 3.0 x $0.5 \mathrm{~m}$ was maintained with pit planting of 10 seed sowing in each pit. Pit was dug before 15 days of planting with $30 \times 30 \times 30 \mathrm{~cm}^{3}$ and applied 20 ton/ha compost, $120 \mathrm{~kg} / \mathrm{ha} \mathrm{N}, 60$ $\mathrm{kg} / \mathrm{ha} \mathrm{p}$ and $60 \mathrm{~kg} / \mathrm{ha} \mathrm{K}$. Recommended package of practices was followed to raise the normal crops. Data were recorded on 14 important characters related to Growth and fruit characters during the course of investigation which were subjected to statistical analysis using suitable techniques of different characters. The technique of analysis of variance for randomized block design (factorial) was adopted following Panse and Sukhatme (1967).

\section{Results and Discussion}

The analysis of variance for various attributes revealed significant differences among the PGRs. it can be concluded that the foliage application of Ethrel @ 200 ppm was found beneficial for number of fruits per vine, fruit yield (kg/vine), days to $1^{\text {st }}$ harvest, whereas maximum fruit length, fruits weight and fruits girth was obtained by the application of distilled water however maximum vine length, total number of node per vine was obtained by the foliage application of $\mathrm{GA}_{3} @ 150$ ppm.

\section{Growth Character}

Vine Length was increased significantly by PGR application (Table 1). Maximum length $(9.85 \mathrm{~m})$ was observed with GA $150 \mathrm{ppm}$ being significantly superior while minimum $(6.41 \mathrm{~m})$ in Ethrel $200 \mathrm{ppm}$. Number of primary branches per vine was significantly increased by PGR application and ethrel 200 ppm was found most effective (20.05). Number of nodes per vine was found significantly higher (52.11) in GA $150 \mathrm{ppm}$ while their interaction was non-significant. 
Among the treatment combination number of nodes was maximum in $\mathrm{GA}_{3}-150 \mathrm{ppm}$ (52.11).

PGR significantly reduced the number of days taken for appearance of first male flower. Ethrel 200 ppm was found the best with minimum of 46.33 days. Similarily, Ethrel 200 ppm significantly reduced the number of days (40.37 days) taken for appearance of first male flower

Node number of first male flower was significantly reduced by PGR and the lowest was in Ethrel 200 ppm (8.20). Similarly, Ethrel $200 \mathrm{ppm}$ significantly decreased the node number of first female flower (11.02).

The increased vine length, Number of primary branches and Days to first female and male flower by $\mathrm{GA}_{3}$ and ethrel might be due to the mechanism of $\mathrm{GA}_{3}$ in the apex, protein synthesis, cell division, auxins production, cell expansion and elongation of vine of the bottle gourd. Mishra et al., (1972) showed that GA was most effective in increasing the length of vine which was also supported by Arora et al., (1985). Ethrel reduced the growth which might be due to decrease in level of gibberellins as also reported by Rudich et al., (1970). Application of ethrel caused reduction of vine length and induction of dwarfism had resulted in the increased number of branches. This result was in accordance with the finding of Arora and Pratap (1989) with ethrel in Pumpkin. Application of ethrel caused reduction of days for first male flower appearance. The results obtained are in agreement with those Baruas and Das (1997) in Bottle gourd, respectively. Application of ethrel caused reduction of days for first female flower appearance. The results obtained are in agreement with Verma et al., (1984) in bitter gourd.

Table.1 Effect of plant growth regulators on growth trait

\begin{tabular}{|l|l|l|l|l|l|l|l|l|}
\hline Chemical & $\begin{array}{l}\text { Concentr } \\
\text { ation }\end{array}$ & $\begin{array}{l}\text { Vine } \\
\text { length } \\
\text { (m) }\end{array}$ & $\begin{array}{l}\text { No } \\
\text { prim. } \\
\text { branches/ } \\
\text { vine }\end{array}$ & $\begin{array}{l}\text { Number } \\
\text { of node } \\
\text { per vine }\end{array}$ & $\begin{array}{l}\text { Days to } \\
\text { first } \\
\text { male } \\
\text { flower }\end{array}$ & $\begin{array}{l}\text { Days to } \\
\text { first } \\
\text { female } \\
\text { flower }\end{array}$ & $\begin{array}{l}\text { Node no of } \\
\text { first } \\
\text { flower } \\
\text { male }\end{array}$ & $\begin{array}{l}\text { Node no of } \\
\text { first female } \\
\text { flower }\end{array}$ \\
\hline Ethrel & $100 \mathrm{ppm}$ & 6.85 & 16.53 & 46.76 & 47.25 & 42.84 & 8.96 & 11.12 \\
\hline Ethrel & $200 \mathrm{ppm}$ & 6.41 & 20.05 & 45.20 & 46.33 & 40.37 & 8.20 & 11.02 \\
\hline Ethrel & $300 \mathrm{ppm}$ & 7.04 & 18.05 & 46.12 & 48.73 & 41.37 & 8.36 & 11.64 \\
\hline NAA & $50 \mathrm{ppm}$ & 7.26 & 16.26 & 48.00 & 50.55 & 43.82 & 9.85 & 12.75 \\
\hline NAA & $100 \mathrm{ppm}$ & 7.74 & 15.04 & 48.40 & 52.35 & 44.14 & 10.10 & 13.00 \\
\hline NAA & $150 \mathrm{ppm}$ & 8.05 & 15.38 & 48.60 & 54.12 & 45.43 & 10.64 & 13.08 \\
\hline GA 3 & $50 \mathrm{ppm}$ & 8.15 & 14.26 & 49.18 & 54.76 & 47.65 & 10.84 & 13.15 \\
\hline GA & $100 \mathrm{ppm}$ & 9.25 & 13.30 & 49.60 & 55.33 & 48.38 & 11.45 & 13.45 \\
\hline GA & $150 \mathrm{ppm}$ & 9.85 & 12.68 & 52.11 & 55.71 & 50.38 & 11.65 & 13.85 \\
\hline $\begin{array}{l}\text { Distilled water } \\
\text { Spray }(\text { control) }\end{array}$ & - & 8.02 & 11.32 & 44.06 & 53.86 & 46.13 & 10.62 & 12.68 \\
\hline S.Em. $\mathbf{E}$ & 0.426 & 0.894 & 2.335 & 2.410 & 2.238 & 0.526 & 0.739 & 0.426 \\
\hline C.D. at 5\% & & 0.895 & 1.878 & NS & 5.064 & 4.702 & 1.105 & 1.554 \\
\hline C.V. \% & & 6.64 & 7.16 & 5.98 & 5.69 & 6.08 & 6.40 & 7.21 \\
\hline
\end{tabular}


Table.2 Effect of plant growth regulators on fruit character

\begin{tabular}{|c|c|c|c|c|c|c|c|c|}
\hline Chemical & $\begin{array}{l}\text { Concent } \\
\text { ration }\end{array}$ & \begin{tabular}{|l|} 
Days to \\
first \\
harvesting
\end{tabular} & $\begin{array}{l}\text { Fruit } \\
\text { Length } \\
\text { (cm) }\end{array}$ & $\begin{array}{l}\text { Fruit } \\
\text { diameter } \\
\text { (cm) }\end{array}$ & $\begin{array}{l}\text { Avg. } \\
\text { fruit } \\
\text { weight } \\
\text { (kg) }\end{array}$ & $\begin{array}{l}\text { No of } \\
\text { fruit per } \\
\text { vine }\end{array}$ & \begin{tabular}{|l}
$\begin{array}{l}\text { Fruit } \\
\text { yield } \\
\text { (Kg/ } \\
\text { vine) }\end{array}$ \\
\end{tabular} & $\begin{array}{l}\text { Yield/ } \\
\text { Plot }\end{array}$ \\
\hline Ethrel & 100 ppm & 54.80 & 34.86 & 27.64 & 1.32 & 8.66 & 11.43 & 55.15 \\
\hline Ethrel & $200 \mathrm{ppm}$ & 54.00 & 36.62 & 27.84 & 1.45 & 10.36 & 15.02 & 70.28 \\
\hline Ethrel & $300 \mathrm{ppm}$ & 55.33 & 35.16 & 28.16 & 1.40 & 9.78 & 13.69 & 65.39 \\
\hline NAA & $50 \mathrm{ppm}$ & 56.78 & 34.08 & 26.21 & 1.30 & 7.85 & 10.20 & 49.84 \\
\hline NAA & $100 \mathrm{ppm}$ & 57.66 & 33.26 & 25.70 & 1.25 & 7.58 & 9.47 & 46.78 \\
\hline NAA & $150 \mathrm{ppm}$ & 58.00 & 31.06 & 22.26 & 1.15 & 7.46 & 8.58 & 43.04 \\
\hline $\mathbf{G A}_{3}$ & $50 \mathrm{ppm}$ & 60.66 & 33.54 & 25.86 & 1.28 & 7.65 & 9.79 & 48.12 \\
\hline $\mathbf{G A}_{3}$ & 100 ppm & 61.33 & 32.12 & 24.35 & 1.18 & 7.42 & 8.75 & 43.75 \\
\hline $\mathbf{G A}_{3}$ & $150 \mathrm{ppm}$ & 63.66 & 30.74 & 21.18 & 1.12 & 7.18 & 8.04 & 40.77 \\
\hline $\begin{array}{l}\text { Distilled } \\
\text { water spray } \\
\text { (control) }\end{array}$ & - & 59.60 & 37.86 & 29.22 & 1.48 & 6.84 & 10.12 & 49.51 \\
\hline S.Em. \pm & & 2.558 & 1.647 & 1.324 & 0.060 & 0.374 & 0.701 & 3.140 \\
\hline C.D. at 5\% & & 5.375 & 3.461 & 2.782 & 0.128 & 0.786 & 1.473 & 6.597 \\
\hline C.V. \% & & 5.39 & 5.95 & 6.28 & 5.77 & 5.68 & 8.17 & 7.50 \\
\hline
\end{tabular}

Application of ethrel caused reduction of Node number of first male flower. Similar results also reported by Sidhu et al., (1982) in Muskmelon and Node number of first female flower Similar results also reported by (Heslop-Harrison, 1957).

\section{Fruit Character}

With respect to fruit characters, PGR showed significant effect (Table 2). Ethrel -200ppm significantly reduced days to first harvesting (54.00 days) which was statistically at par with the treatment $\mathrm{T}_{6}$ NAA $-150 \mathrm{ppm}$ (58.00 days), $\mathrm{T}_{5}$ NAA $100 \mathrm{ppm}$ (57.66 days), $\mathrm{T}_{4}$ NAA50ppm (56.78 days), $\mathrm{T}_{3}$ Ethrel 300ppm (55.33 days) and $\mathrm{T}_{1}$ Ethrel 100ppm (54.58 days).

Length of fruit increased significantly with PGR maximum $(37.86 \mathrm{~cm})$ long fruits with the application of distilled water (control) (Table 2). The maximum diameter of fruit $(29.22 \mathrm{~cm})$ was recorded by application of distilled water which showed significant effect.

Average maximum fruit weight $(1.48 \mathrm{~kg})$ was increased significantly by the application of distilled water which was statistically at par with $\mathrm{T}_{2}$ Ethrel $200 \mathrm{ppm}(1.45 \mathrm{~kg})$ and $\mathrm{T}_{3}$ Ethrel $300 \mathrm{ppm}(1.40 \mathrm{~kg})$. PGR significantly increased number of fruits per vine and Ethrel 200 ppm gave maximum (10.36 fruit/vine).

The highest Fruit yield (kg/ vine) was recorded in treatment $\mathrm{T}_{2}$ Ethrel $200 \mathrm{ppm}(15.02 \mathrm{~kg})$ which was statistically at par with treatment $\mathrm{T}_{3}$ Ethrel $300 \mathrm{ppm}(13.79 \mathrm{~kg})$. The data revealed that fruit yield of bottle gourd per plot was significantly increased by various treatments. The maximum fruit yield per plot was recorded in treatment $\mathrm{T}_{2}$ Ethrel $200 \mathrm{ppm}(70.28 \mathrm{~kg})$ which was statistically at par with treatment $T_{3}$ Ethrel 300 ppm $(65.39 \mathrm{~kg})$.

The increased number of fruits per vine (Mandai et al., (1990) and Kumar et al., (2006) 
in bottle gourd), Fruit yield (kg/ vine) (Parmar (2003) in sponge gourd), days to first harvesting and yield of bottle gourd per plot (These findings are also in consonance with those of Arora et al., (1988) in sponge gourd; Das and Maurya (1993) in pumpkin) by application of Ethrel 200 ppm.

\section{Acknowledgement}

Authors acknowledge with thanks to the Chairman, Department of Horticulture (Vegetable \& Floriculture), Director Research and Dean, Post Graduate Studies, Bihar Agricultural University, Sabour, Bhagalpur for providing necessary facilities during the course of investigation.

\section{References}

Arora SK, Pandita ML, Pratap PS, Sidhu AS (1985). Effect ethaphon, Gibberellic acid and maleic hydrazide on vegetative growth, flowering and fruiting of cucurbitaceous crops. J. American Society of Horticulture science; 110(3): 442-445.

Arora SK. and Pratap PS (1988). Effect of plant growth regulators on vegetative growth, flowering, fruit yield in pumpkin (Cucurbita moschata Duch. Ex. Poir). Haryana Agric. Uni. J. Res., 18(4): 284290.

Baruas GKS and Das RK 1997. Effect of plant growth regulators on yield of bottle gourd at different sowing dates. Annals of Agricultural Research, 18 (3): 371-374

Das TK. and Maurya AN (1993). Efficacy of growth regulating substances on different attributes of yield of Cucurbita moschata
Poir. Orissa Journal of Agriculture Research, 5(1-2): 69-74

Hidayatullah T, Mahmood M, Farooq M.A. Khokhar and Hussain SI (2012). Plant growth regulators affecting sex expression of bottle gourd (Lagenaria siceraria molina) plants. Pakistan Jornel of Agriculture research. 25(1):50-54.

Kumar S, Dixit SK and Mishra HR (2006). Effect of plant growth regulators on yield and yield attributing characters of bottle gourd. Advances of Plant Science, 19 (2): 419-421.

MandaI D, Paria N C and Maity T K (1990). Response of bottle gourd (Lagenaria siceraria Molina Standi) to some plant growth regulators. Crop Research, 3 (2): 244-246.

Mishra GM, Prasad B, Sinha SC (1972). Effect of plant growth regulators on growth, sex expression and yield of bottle gourd. Third International Symposium on Subtropical and Tropical. Horticulture Science; 9:159-166.

Panse VG. And Sukhatme PV (1967).Statistical methods for agricultural workers, ICAR, New Delhi.pp.152-161.

Parmar HM. (2003). Effect of plant growth regulators on growth, sex expression and yield of sponge gourd [Luffa cylindrica (linn.) M. Roem.] cv. Pusa Chikni M.Sc. (Agri.) thesis submitted to Gujarat Agril. University, Anand.

Rudich J, Halvey AH, Kedar N (1970). Changed sex expression and possibilities for F1 hybrid seed production in some cucurbits by application of ethrel and Alar. Euphytica; 19: 47-53.

\section{How to cite this article:}

Komal Kumari, Kamalkant, Randhir Kumar and Vijay Kumar Singh. 2019. Effect of Plant Growth Regulators on Growth and Yield of Bottle Gourd (Lagenaria siceraria (Mol.) Standl.). Int.J.Curr.Microbiol.App.Sci. 8(07): 1881-1885. doi: https://doi.org/10.20546/ijcmas.2019.807.223 